\title{
Modeling of heat and mass transfer in the process of drying of colloid capillary-porous materials
}

\author{
Zh.O. Petrova (ORCID 0000-0001-7385-8495), B.V. Davydenko (ORCID 0000-0001-8738-7612), \\ K.S. Slobodianiuk (ORCID 0000-0003-3416-388X) \\ Institute of Engineering Thermophysics of NAS of Ukraine, str. Bulakhovskogo, 2, Bldg. 2, Kyiv, 03164, Ukraine \\ Tel.: +380444249639, +380444249644 \\ E-mail: bergelzhanna@ukr.net,bdavydenko@ukr.net,ironket@gmail.com
}

Article info: received 07.05.2019, revised 27.05.2019, accepted 14.06.2019

Petrova, Zh.O., Davydenko, B.V., Slobodianiuk, K.S. (2019) Modeling of heat and mass transfer in the process of drying of colloid capillary-porous materials 2(43), doi: 10.26909/csl.2.2019.1

The process of drying is an energy-consuming process, therefore, in order to optimize these energy costs during drying and to choose the rational structural and regime parameters of the equipment intended for this process, it is necessary to carry out a calculation analysis of heat and mass transfer on the basis of adequate mathematical models. The study of various mechanisms of diffusion in capillary-porous materials has become the basis for the creation of a mathematical model of heat-mass transfer and for the formulation of a corresponding system of nonlinear differential equations. Using mathematical model of heat-mass transfer A.V. Lykova constructed an appropriate numerical algorithm for modeling this process, numerical studies of the convection drying process of colloidal capillary-porous materials (KKPM) have been performed. The boundary conditions on the contact surface of the material in the drying chamber with the heat carrier flow are formulated. Based on the numerical solution of the system of one-dimensional heat and mass transfer equations in the material, depending on the time of its specific moisture content and temperature, as well as other characteristics of the convection drying process, the dependence was obtained. The estimated results are compared with the results of experimental studies. From the results of the comparison, it follows that the calculated model on the basis of the proposed system of equations satisfactorily describes the process of mass transfer in colloidal capillary-porous materials and can be used to approximate the characteristics of the drying process of colloidal capillary-porous materials, in particular the time required for drying the material. Numerical modeling of heat and mass transfer processes in colloid capillary and porous materials helps to solve an important scientific and technical problem, which is connected with the creation of software and hardware complexes, automated systems of scientific researches of energy-saving heat-technological processes of drying of materials with the provision of necessary quality indicators. Having analyzed the literature data concerning the existing developed mathematical modeling of colloidal capillary-porous materials, it has been established that this direction has a limited amount of information and therefore requires in-depth study and is an actual direction of research.

Key words: capillary-porous materials, convection drying process, mathematical model of heat-mass transfer.

\section{Моделювання тепломасопереносу в процесі сушіння колоїдних капілярно-пористих матеріалів}

\author{
Ж.О. Петрова, Б.В. Давиденко, К.С. Слободянюк \\ Інститут технічної теплофізики НАН України, Київ, Україна
}

Процес сушіння - енерговитратний процес, отже для оптимізації цих витрат енергії при сушінні та вибору раціональних конструкційних та режимних параметрів обладнання, призначеного для здійснення цього процесу, необхідно виконувати розрахунковий аналіз тепломасообміну на основі адекватних математичних моделей. Дослідження різних механізмів дифузії в капілярно-пористих матеріалах стало основою для створення математичної моделі тепломасопереносу та для формулювання відповідної системи нелінійних диференційних рівнянь. 3 застосуванням математичної моделі тепломасопереносу А.В. Ликова побудовано відповідний чисельний ал- 
горитм для моделювання цього процесу, виконано чисельні дослідження процесу конвекційного сушіння колоїдних капілярно-пористих матеріалів (ККПМ). Сформульовано граничні умови на поверхні контакту матеріалу, що знаходиться в сушильній камері, з потоком теплоносія. За результатами чисельного розв'язання системи одновимірних рівнянь тепломасопереносу в матеріалі одержано залежності від часу його питомого вологовмісту та температури, а також інші характеристики процесу конвекційного сушіння. Розрахункові результати порівнюються з результатами експериментальних досліджень. 3 результатів порівняння випливає, що розглянута розрахункова модель на основі запропонованої системи рівнянь достатньо задовільно описує процес масопереносу в колоїдних капілярно-пористих матеріалах і може бути використана для наближеного визначення характеристик процесу сушіння колоїдних капілярно-пористих матеріалів, зокрема часу, необхідного для висушування матеріалу. Чисельне моделювання тепломасообмінних процесів у колоїдних капілярно-пористих матеріалах допомагає вирішенню важливої науково-технічної проблеми, що пов'язана зі створенням програмно-технічних комплексів, автоматизованих систем наукових досліджень енергоощадних теплотехнологічних процесів сушіння матеріалів iз забезпеченням необхідних показників якості. Проаналізувавши літературні дані стосовно існуючого розробленого математичного моделювання колоїдних капілярно-пористих матеріалів встановлено, що даний напрям має обмежену кількість інформації і тому потребує поглибленого вивчення та є актуальним напрямком досліджень.

\section{Вступ}

Сушіння - це процес видалення вологи 3 матеріалу, що супроводжується зміною його структурно-механічних, технологічних та біологічних властивостей. Капілярно-пористі колоїдні тіла мають капілярно-пористу будову, а стінки капілярів мають властивості обмежено набухлих колоїдних тіл (шкіра, тканина, деревина) [1]. Процес сушіння вимагає суттєвих витрат енергії. Для оптимізації цих витрат при сушінні та вибору раціональних конструкційних та режимних параметрів обладнання, призначеного для здійснення цього процесу, необхідно виконувати розрахунковий аналіз тепломасообміну на основі адекватних математичних моделей.

3 розвитком фундаментальної теорії тепло- i масопереносу, переважно завдяки роботам А.В. Ликова та його школи, усе частіше стали застосовуватися напівемпіричні математичні моделі для розрахунку процесів сушіння. Дослідження різних механізмів дифузії в капілярно-пористих матеріалах стало основою для створення математичної моделі тепломасопереносу та для формулювання відповідної системи нелінійних диференційних рівнянь [2]. Розвиток обчислювальної техніки та впровадження в розрахункову практику чисельних методів дозволило моделювати складні нестаціонарні процеси тепломасопереносу $[3,4]$. Водночас на сьогоднішній день залишається актуальною проблема побудови адекватних математичних моделей та методів чисельних досліджень тепломасопереносу в колоїдних капілярно-пористих матеріалах [5]. Це є наслідком суттєвої складності фізичних явищ, що супроводжують процес їх сушіння.

Мета роботи полягає у визначені можливості застосування математичної моделі тепломасопереносу А.В. Ликова для розрахунків характеристик процесу сушіння колоїдних капілярно-пористих матеріалів. Також метою роботи $є$ формулювання граничних умов та побудова відповідного чисельного алгоритму для моделювання цього процесу. Це дасть можливість дослідити закономірності цих процесів, а також вдосконалити існуючі та розробити нові технології конвекційного сушіння [6].

\section{Матеріали та методи дослідження}

Дослідження процесу сушіння колоїдних капілярно-пористих матеріалів виконуються методом чисельного моделювання та експериментальним методом. Процес конвекційного сушіння схематично відображено на рис.1. Зразок ККПМ зверху і знизу обдувається розігрітим повітрям.

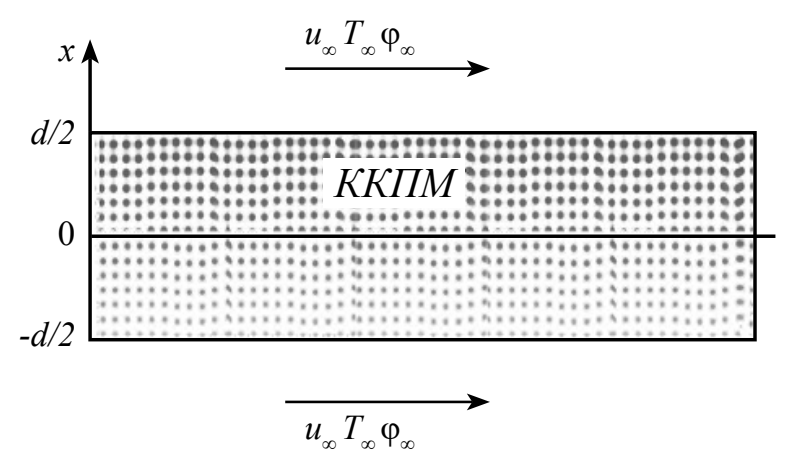

Рис. 1. Схема до фізичної моделі процесу конвекційного сушіння

Процес сушіння передбачає підвід теплоти конвекцією від розігрітого повітряного потоку до матеріалу, що висушується. Зразок матеріалу, що має форму прямокутного паралелепіпеда, знаходиться в сушильній камері, у яку подається розігрітий теплоносій. Розрахункові дослідження тепломасопереносу в колоїдному капілярно-пористому матері- 
алі виконуються на основі чисельного розв'язання системи рівнянь [7], до якої входять:

- рівняння переносу вологи

$$
\frac{\partial U}{\partial \tau}=\operatorname{div}\left(a_{m} \cdot \operatorname{grad}(U)\right)+\operatorname{div}\left(a_{m} \delta_{t} \cdot \operatorname{grad}(T)\right) ;
$$

- рівняння переносу енергії

$$
c \rho \frac{\partial T}{\partial \tau}=\operatorname{div}(\lambda \cdot \operatorname{grad}(T))+r \varepsilon \frac{\partial U}{\partial \tau},
$$

де $U$ - питомий вологовміст матеріалу (сумарна маса рідкої вологи та водяної пари в одинці об' $\epsilon-$

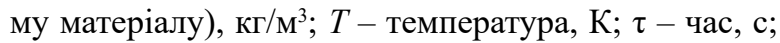
$a_{m}$ - коефіцієнт дифузії вологи в колоїдному капілярно-пористому матеріалі, $\mathrm{M}^{2} / \mathrm{c} ; \delta_{t}$ - термоградієнтний коефіцієнт, кг $\left(\mathrm{M}^{3} \cdot \mathrm{K}\right) ; c$ - ефективна теплоємність матеріалу, Дж/(кг·К); $\rho$ - ефективна густина матеріалу, кг/м³ $; \lambda$ - ефективна теплопровідність матеріалу; $r$ - питома теплота випаровування, Дж/кг; $\varepsilon$ - коефіцієнт фазового перетворення, що характеризує відношення потоку водяної пари до сумарного потоку рідкої вологи та потоку пари. Його величина змінюється в межах від 0 до 1.

Задача тепломасопереносу в зразку ККПМ розглядається в наближеній одновимірній постановці. Процес сушіння вважається симетричним відносно площини симетрії прямокутного зразка, що розглядається. Для випадку відносно малої товщини зразка $d$, а також при невисоких градієнтах температури, переносом вологи термодифузією можна знехтувати. За даних припущень систему рівнянь (1), (2) доцільно представити у вигляді

$$
\begin{gathered}
\frac{\partial U}{\partial \tau}=\frac{\partial}{\partial x}\left(a_{m} \frac{\partial U}{\partial x}\right) \\
c \rho \frac{\partial T}{\partial \tau}=\frac{\partial}{\partial x}\left(\lambda \frac{\partial T}{\partial x}\right)+r \varepsilon \frac{\partial}{\partial x}\left(a_{m} \frac{\partial U}{\partial x}\right)
\end{gathered}
$$

де $x$ - напрямок від площини симетрії зразка, де $x=0$, до поверхні тепломасообміну, для якої $x=d / 2$.

Граничні умови до рівнянь (3), (4) на поверхні тепломасообміну мають вигляд

$$
\begin{gathered}
-\left.a_{m} \frac{\partial U}{\partial x}\right|_{x=d / 2}=\beta\left(C_{v, w}-C_{v, \infty}\right) \\
-\left.\lambda \frac{\partial T}{\partial x}\right|_{x=d / 2}=\alpha\left(T_{w}-T_{\infty}\right)+r\left(1-\varepsilon_{w}\right) \beta\left(C_{v, w}-C_{v, \infty}\right),
\end{gathered}
$$

де $\mathrm{C}_{v, w}$ - відносна концентрація водяної пари в теплоносії біля поверхні тепломасообміну; $C_{v, \infty}-$ відносна концентрація водяної пари в теплоносії на значній відстані від поверхні; $T_{w}$ - температура поверхні тепломасообміну; $T_{\infty}$ - температура теплоносія на значній відстані від поверхні; $\alpha$ - коефіцієнт тепловіддачі, Вт/( $\left.{ }^{2} \cdot K\right) ; \beta$ - коефіцієнт масовіддачі, $\kappa \Gamma /\left(\mathrm{M}^{2} \cdot \mathrm{c}\right)$.

Граничні умови на площині симетрії мають вигляд

$$
\begin{aligned}
& \left.\frac{\partial U}{\partial x}\right|_{x=0} ; \\
& \left.\frac{\partial T}{\partial x}\right|_{x=0}
\end{aligned}
$$

Умова (5) встановлює рівність між сумарним потоком рідкої та пароподібної вологи, що надходить до поверхні з середини матеріалу, та потоком пари, що видаляється 3 поверхні матеріалу та надходить до теплоносія. В правій частині виразу (5) міститься різниця між відносною концентрацією водяної пари у повітрі біля поверхні тепломасообміну $\left(C_{v, w}\right)$ та відносною концентрацією водяної пари в теплоносії на значній відстані від цієї поверхні $\left(C_{v, \infty}\right)$. Величина $C_{v, \infty}$ має бути відомою з початкових умов задачі, так само як і температура теплоносія $T_{\infty}$. Величина $C_{v, w}$ визначається в ході розв'язання задачі в залежності від вологісного стану поверхні матеріалу. Як запропоновано в [8], у випадку, коли вологовміст матеріалу біля поверхні масообміну перевищує величину максимального гігроскопічного вологовмісту, концентрація водяної пари визначається з умов для насиченої пари, що відповідають температурі цієї поверхні. Якщо вологовміст матеріалу біля поверхні менший за максимальне гігроскопічне значення, концентрація водяної пари визначається з ізотерми сорбції за величинами вологовмісту матеріалу біля поверхні та температури цієї поверхні.

Ізотерми сорбції зазвичай представляються у вигляді експериментально визначеної залежності рівноважної концентрації рідини у зразку $W$ від відносної вологості повітря $\varphi=p_{v} / p_{v, s}$. Для їі застосування при розв'язанні системи рівнянь (3), (4) цю залежність доцільно перебудувати у вигляді залежності рівноважного питомого вологовмісту матеріалу $U$ від відносної концентрації водяної пари у повітрі $C_{v, w}=\rho_{v, w} /\left(\rho_{v, w}+\rho_{a, w}\right)$. Для цього за величиною питомого вологовмісту на поверхні $U_{w}$ визначається відносна концентрація вологи у матеріалі

$$
W_{w}=\frac{U_{w}}{U_{w}+m_{c} / V},
$$

де $m_{\text {c }}$ - маса сухого матеріалу; $V$ - об'єм зразка.

За значеннями $W_{w}$ та температури поверхні $T_{w}$ по ізотермі сорбції визначається відповідна величина 
відносної вологості повітря чення відносної концентрації водяної пари в повітрі розраховується за формулою

$$
C_{v, w}=\frac{1}{1+\left(\frac{p_{0}}{\varphi p_{v, s}\left(T_{w}\right)}-1\right) \frac{R_{v}}{R_{a}}},
$$

де $p_{0}$ - тиск у пароповітряній суміші; $p_{v}$ - парціальний тиск водяної пари; $p_{v, s}$ - парціальний тиск насиченої водяної пари при температурі $T_{w} ; R_{v}, R_{a}$ - газові сталі для водяної пари та сухого повітря відповідно.

Коефіцієнт тепловіддачі з поверхні тепломасообміну визначається з відповідного рівняння подібності, що враховує режим течії теплоносія. У випадку, коли горизонтальний плоский зразок омивається турбулентним повітряним потоком, для розрахунку коефіцієнта тепловіддачі можна скористатися рівнянням [9]

$$
\mathrm{Nu}_{l}=0,037 \operatorname{Re}_{l}^{0,8} \operatorname{Pr}_{a}{ }^{0,43}\left(\operatorname{Pr}_{a} / \operatorname{Pr}_{w}\right)^{0,25},
$$

де $\mathrm{Nu}_{l}=\frac{\alpha l}{\lambda_{a}}$ - осереднене по поверхні теплообміну довжиною $l$ число Нуссельта; $\operatorname{Re}=\frac{u_{\infty} l}{v_{a}}-$ число Рейнольдса; $\operatorname{Pr}_{a}=\frac{v_{a}}{a_{a}}-$ число Прандтля для повітря; $u_{\infty}$ - швидкість незбуреного повітряного потоку; $v_{\mathrm{a}}$ - кінематичний коефіцієнт в'язкості для повітря.

Коефіцієнт масовіддачі $\beta$ можна за аналогією між теплопереносом та масопереносом визначити 3 наближеного співвідношення

$$
\beta \approx \frac{\alpha}{C_{a}} .
$$

На відміну від граничних умов теплообміну третього роду на поверхні сухого матеріалу, граничні умови (6) для волого матеріалу враховують теплоту випаровування рідкої вологи з поверхні. Ця теплота визначається другою складовою, що входить у праву частину виразу (6).

Коефіцієнт фазового перетворення $\varepsilon_{w}$ на поверхні тепломасообміну, що входить до граничної умови (6), визначає співвідношення між потоком водяної пари, що надходить до поверхні з середини зразка, до сумарного потоку пари та рідкої вологи. Якщо поверхня перезволожена, як це в ряді випадків має місце на початковій стадії сушіння, коефіцієнт $\varepsilon_{w}$ можна прийняти рівним нулю. Це означає, що водяна пара утворюється лише на самій поверхні теломасообміну і не надходить до поверхні з середини зразка.

На заключній стадії сушіння, коли поверхня майже висушена, а випаровування здійснюється в глибинних шарах зразка, коефіцієнт $\varepsilon_{w}$ матиме значення, близьке до одиниці. Це означає, що до поверхні тепломасообміну волога 3 середини зразка надходить лише у вигляді водяної пари. В цьому випадку на самій поверхні фазового перетворення не відбувається.

У цілому ж точне визначення величини $\varepsilon_{w}$ може бути достатньо проблематичним. В першому наближенні можна прийняти $\varepsilon_{w}=0$, коли відносна вологість матеріалу біля поверхні тепломасообміну перевищує максимальне гігроскопічне значення, яке відповідає $\varphi=100 \%$ і температурі поверхні матеріалу. Якщо відносна вологість матеріалу біля поверхні менша за максимальну гігроскопічну вологість, можна припустити, що значення $\varepsilon_{\mathrm{w}} \sim 1$ [10].

Для чисельного розв'язання системи рівнянь (3), (4) 3 граничними умовами (5) - (8) застосовується метод скінчених різниць. Для його використання розрахункова область $0 \leq x \leq d / 2$ розподіляється на $m$ кроків довжиною $\Delta x=d /(2 m)$. Всередині кожного кроку визначаються розрахункові вузли, у яких записуються дискретні аналоги диференціальних рівнянь (3), (4). Таким чином будується різницева розрахункова сітка. Скінчено-різницеві рівняння складаються за неявною часовою схемою [11] і мають вигляд

$$
\begin{gathered}
\frac{U_{k, i}-U_{k-1, i}}{\Delta \tau}=\frac{1}{\Delta x}\left(\left(a_{m}\right)_{k-1, i+1 / 2} \frac{U_{k, i+1}-U_{k, i}}{\Delta x}-\right. \\
\left.-\left(a_{m}\right)_{k-1, i-1 / 2} \frac{U_{k, i}-U_{k, i-1}}{\Delta x}\right) ;
\end{gathered}
$$

$$
\begin{gathered}
(C \rho)_{k-1, i} \frac{T_{k, i}-T_{k-1, i}}{\Delta \tau}=\frac{1}{\Delta x}\left((\lambda)_{k-1, i+1 / 2} \frac{T_{k, i+1}-T_{k, i}}{\Delta x}-\right. \\
\left.-(\lambda)_{k-1, i-1 / 2} \frac{T_{k, i}-T_{k, i-1}}{\Delta x}\right)+ \\
+\frac{r_{k-1, i} \varepsilon_{k-1, i}}{\Delta x}\left(\left(a_{m}\right)_{k-1, i+1 / 2} \frac{U_{k, i+1}-U_{k, i}}{\Delta x}-\right. \\
\left.-\left(a_{m}\right)_{k-1, i-1 / 2} \frac{U_{k, i}-U_{k, i-1}}{\Delta x}\right)
\end{gathered}
$$

де $k$ - номер поточного дискретного кроку за часом; $k$ - 1 - номер попереднього кроку за часом; $i$ - номер кроку за просторовою змінною $x(1 \leq I \leq m)$; $\Delta \tau-$ крок за часом. Дробові індекси при коефіцієнтах рівнянь означають, що відповідна величина визначається, як півсума величин, що відносяться до сусідніх вузлів сітки.

Граничні умови (5) - (8) також представляються в скінчено-різницевій формі:

$$
\begin{gathered}
-\left(a_{m}\right)_{k-1, m+1 / 2} \frac{U_{k, m+1}-U_{k, m}}{\Delta x}= \\
=\beta\left[C_{v, w}\left(U_{k-1, m+1 / 2} ; T_{k-1, m+1 / 2}\right)-C_{v, \infty}\right] ;
\end{gathered}
$$




$$
\begin{gathered}
-(\lambda)_{k-1, m+1 / 2} \frac{T_{k, m+1}-T_{m, i}}{\Delta x}=\alpha\left[\left(\frac{T_{k, m+1}+T_{m, i}}{2}\right)-T_{\infty}\right]+ \\
+r\left(1-\varepsilon_{w}\right) \beta\left[C_{v, w}\left(U_{k-1, m+1 / 2} ; T_{k-1, m+1 / 2}\right)-C_{v, \infty}\right] \\
U_{k, 0}=U_{k, 1} \\
T_{k, 0}=T_{k, 1} .
\end{gathered}
$$

Система різницевих рівнянь (13), (14) 3 граничними умовами (15) - (18) розв'язується методом прогонки [11]. Початковими умовами до нестаціонарних рівнянь (13), (14) є вихідні розподіли температури $T$ та питомого вологовмісту $U$. Для розв'язання задачі задаються також швидкість $u_{\infty}$, температура $T_{\infty}$ та відносна вологість теплоносія $\varphi_{\infty}$. Коефіціснти дифузії $a_{m}$, теплопровідності $\lambda$, теплоємності $c$, а також густина $\rho$ і теплота випаровування $r$, що входять до рівнянь (14) - (19), зазвичай залежать від вологовмісту та температури матеріалу, тобто від невідомих величин, що входять до цих рівнянь. Тому значення цих коефіцієнтів визначаються за величинами $U_{k-1, i}$ та $T_{k-1, i}$, що відносяться до попереднього часового кроку. Надалі значення цих коефіцієнтів уточнюються.

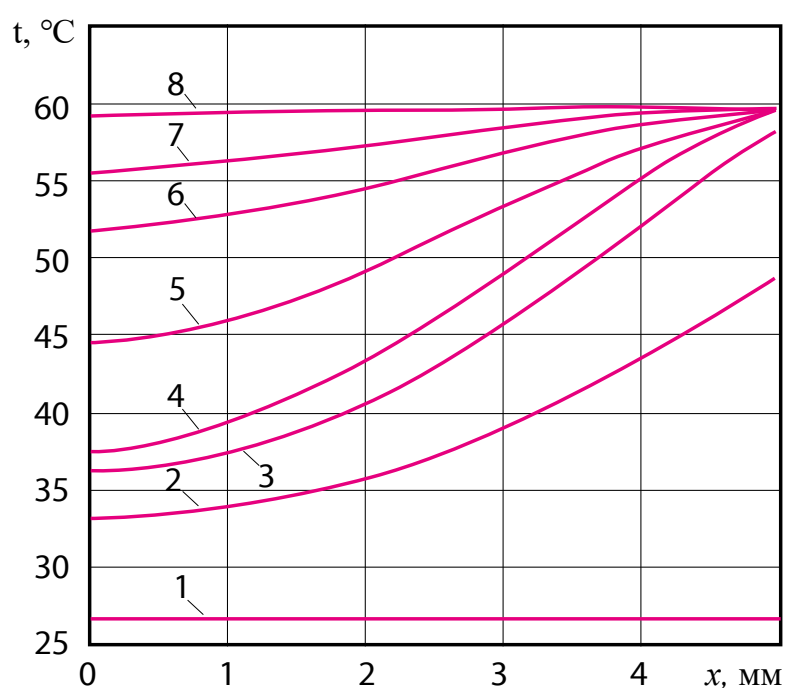

Рис. 2. Розподіл температури по товщині зразка в різні моменти часу при сушінні ККПМ:

$1-$ початковий; $2-\tau=10$ хв; $3-20$ хв; $4-30$ хв; $5-40 \mathrm{xв} ; 6-50 \mathrm{xв} ; 7-60 \mathrm{xв} ; 8-90 \mathrm{xв}$

\section{Результати та їх обговорення}

За наведеним методом виконується чисельне моделювання процесу конвекційного сушіння зразка ККПМ товщиною $d=10$ мм та площею поверхонь $F=1000$ мм² $^{2}$ з яких видаляється волога. Швидкість повітряного потоку в сушильній камері $u_{\infty}=3,5 \mathrm{M} / \mathrm{c}$, його температура $T_{\infty}=60{ }^{\circ} \mathrm{C}$, відносна вологість $\varphi_{\infty}=4,7 \%$. За цих умов $C_{v, \infty}=0,0057$. Початкова маса зразка $m_{0}=9,786$ г. Його початкова температура $T_{0}=26,6^{\circ} \mathrm{C}$. Маса сухого матеріалу $m_{\mathrm{c}}=1,41$ г. Початковий питомий вологовміст складає $U_{0}=837,6$ кг $/ \mathrm{M}^{3}$. Теплофізичні властивості ККПМ приймаються такими, як рекомендовано в [12].

За наведеними вихідними даними крім розрахункових досліджень проведено також експериментальні дослідження 3 метою порівняння їх результатів. Експеримент $з$ висушування зразка ККПМ проводився протягом 90 хв.

Для виконання розрахунків будується різницева сітка, що мітить $m=100$ кроків на половині товщини зразка $d / 2$. Крок за часом складає $\Delta \tau=1 \mathrm{c}$. За результатами чисельного моделювання одержано розподіли по товщині зразка температури (рис. 2) та питомого вологовмісту (рис. 3) в різні моменти часу.

Як видно 3 рис. 2 та 3, найбільш інтенсивно зміна у часі температури та питомого волого-

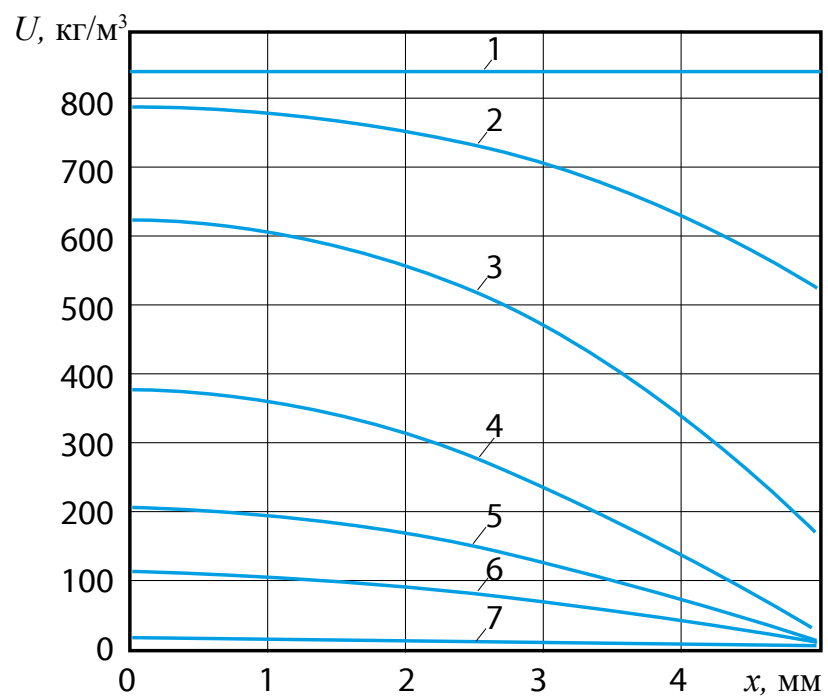

Рис. 3. Розподіл вологовмісту по товщині зразка в різні моменти часу при сушінні:

$1-$ початковий; $2-\tau=10 \mathrm{xв} ; 3-20 \mathrm{xв}$; $4-30 \mathrm{xв} ; 5-40 \mathrm{xв} ; 6-50 \mathrm{xв} ; 7-80$ хв. 


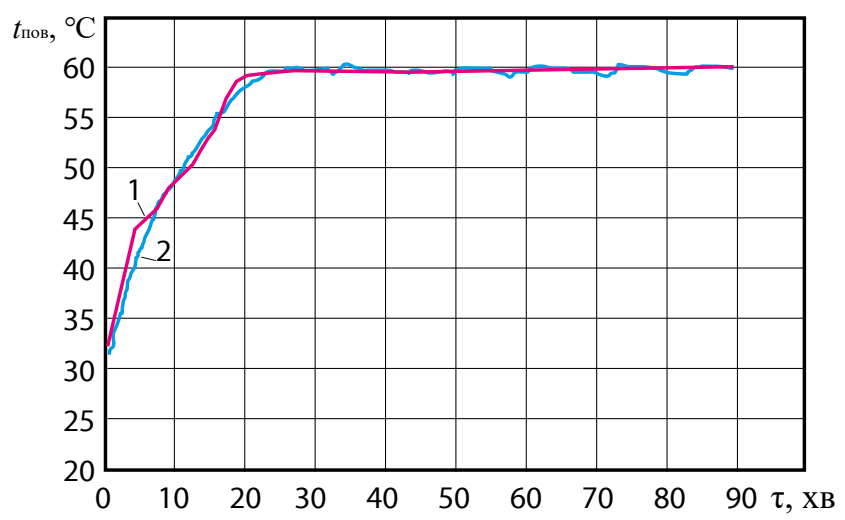

Рис. 4. Зміна у часі температури поверхні зразка ККПМ:

1 - експеримент; 2 - розрахунок за моделлю

вмісту відбувається на поверхні тепломасообміну ( $x=5$ мм). Зміну у часі температури та вологовмісту на поверхні тепломасообміну наведено на рис. 4 та 5 відповідно. На рис. 4 наведено також порівняння результатів розрахунків за наведеною моделлю (крива 2) з результатами експерименту (крива 1). Як видно з цього рисунку, збіг результатів розрахунків температури поверхні з результатами експерименту достатньо задовільний. 3 рисунку також видно, що найбільш інтенсивна зміна температури поверхні відбувається протягом перших 20 хвилин. Найбільш інтенсивна зміна вологовмісту поверхні відбувається протягом перших 30 хвилин.

За визначеною величиною питомого вологовмісту розраховується також зміна у часі сумарної маси вологи у досліджуваному зразку

$$
m_{w}(\tau)=F \cdot \int_{0}^{d / 2} U(\tau, x) d x .
$$

На рис. 6 наведено залежність цієї величини від часу (крива 2) та зміну у часі сумарної маси вологи

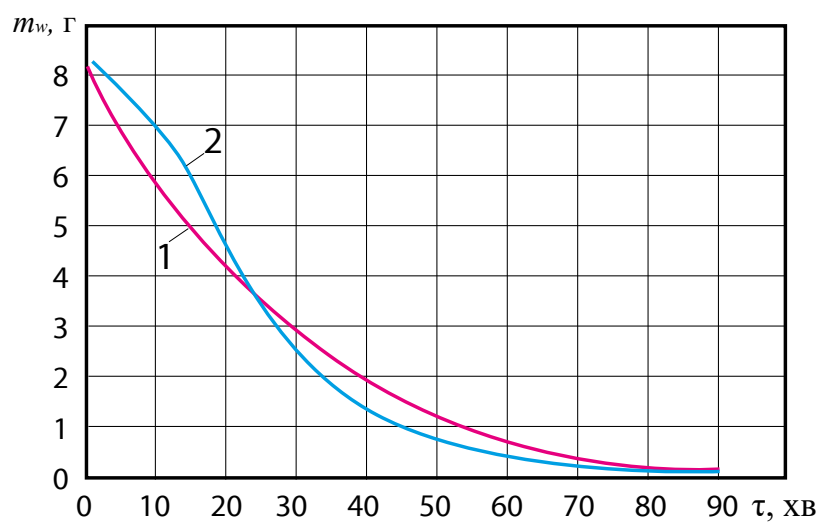

Рис. 6. Зміна у часі маси вологи у зразку, що досліджується:

1 - експеримент; 2 - розрахунок за моделлю

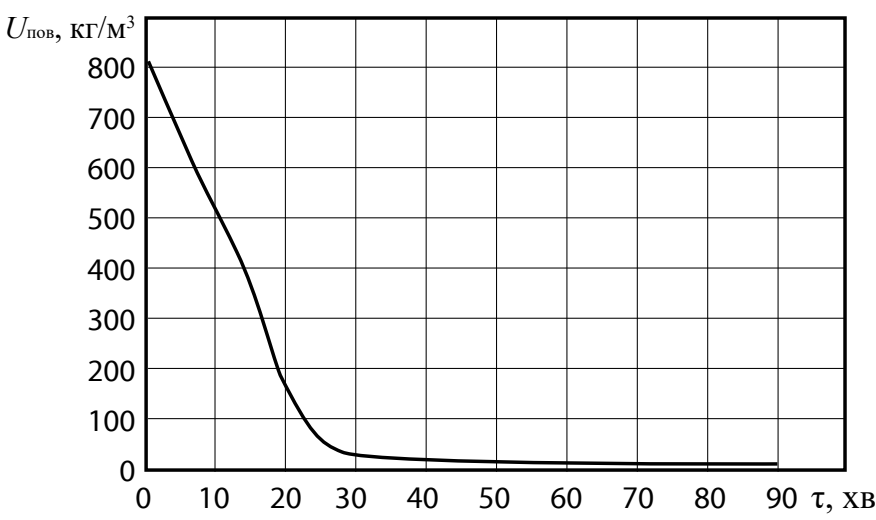

Рис. 5. Зміна у часі вологовмісту на поверхні ККПМ

у досліджуваному зразку, що отримана з експериментальних досліджень (крива 1). Як видно з порівняння цих кривих, на початковій стадії сушіння $(\tau<25$ хв.) маса вологи в зразку, що одержана 3 розрахунків, менша, ніж та, що визначена з експерименту. На наступній стадії сушіння розрахункове значення маси вологи стає меншим, ніж експериментальне.

Визначається також зміна у часі відносної концентрації вологи у зразку $W(\tau)$

$$
W=\frac{m_{w}}{m_{w}+m_{c}} .
$$

Зміну у часі значень цієї величини, що отримані 3 розрахунків та 3 експерименту, представлено на рис. 7.

3 порівняння розрахункових та експериментальних даних випливає, що за даною чисельною моделлю процес сушіння на початковій стадії протікає дещо повільніше, ніж це випливає з експерименту. Надалі інтенсивність висушування матеріалу, що

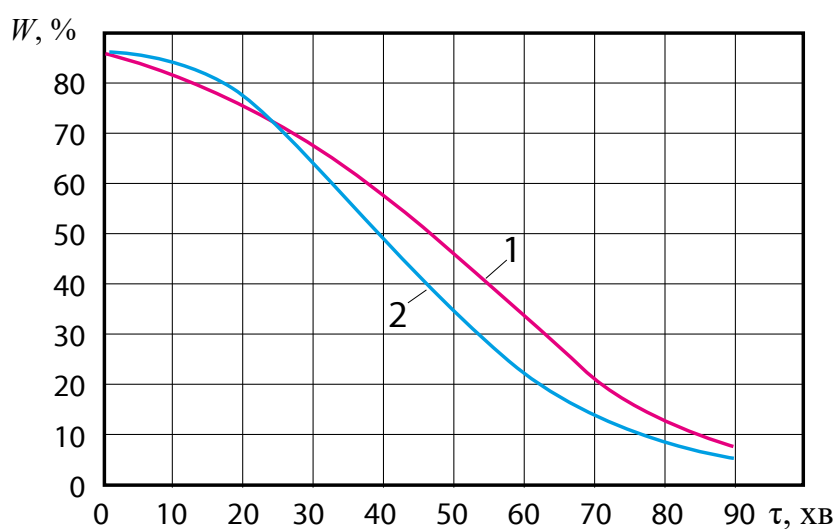

Рис. 7. Зміна у часі відносної концентрації вологи у зразку:

1 - експеримент; 2 - розрахунок за моделлю 


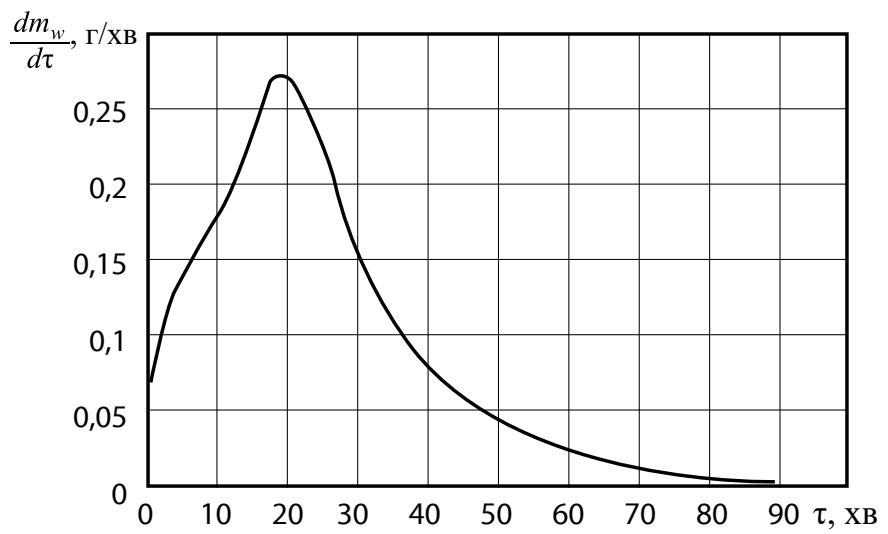

Рис. 8. Залежність від часу швидкості сушіння зразка

визначається 3 розрахунків, виявляється більшою, ніж та, що одержана з експерименту.

За результатами розрахункових досліджень визначається також швидкість конвекційного сушіння досліджуваного зразку $\frac{d m_{w}}{d \tau}$. Залежність цієї величини від часу наведено на рис. 8. Як видно 3 рисунку, на початковій стадії сушіння швидкість цього процесу зростає. Найбільша швидкість сушіння зразка $\frac{d m_{w}}{d \tau}=0,275$ г/хв спостерігається при $\tau=20$ хв. Далі швидкість сушіння починає спадати.

Даний характер зміни у часі швидкості сушіння пояснюється тим, що, як випливає з залежності (5), густина потоку маси 3 поверхні зразка зростає зі збільшенням відносної концентрації водяної пари $C_{v, w}$ біля цієї поверхні. Ця величина збільшується 3 ростом температури поверхні $t_{\text {пов }}$ та зменшується зі зниженням відносної концентрації вологи на поверхні $W_{\text {пов }}$ Оскільки в процесі конвекційного сушіння водночас зростає температура поверхні і зменшується ії̈ вологовміст, величина $C_{v, w}$ залежатиме від того, який саме 3 цих двох параметрів суттєвіше на неї впливає в даний момент часу. Таким чином, від початку сушіння величина $C_{v, w}$ зростає і при $\tau=20$ хв набуває максимального значення, а далі з часом починає спадати.

Залежність від часу швидкості зміни відносної вологості зразка $\frac{d W}{d \tau}$ має аналогічний характер (рис. 9). Але максимального значення $\frac{d W}{d \tau}=1,54 \% /$ хв. ця величина набуває при $\tau=38$ хв.

За результатами розрахункових досліджень будується також залежність швидкості зміни відносної вологості зразка $\frac{d W}{d \tau}$ від величини самої відносної вологості (крива сушіння). Ця залежність наведена на рис. 10. Як видно з рисунку, максимального значення $\frac{d W}{d \tau}=54 \% /$ хв. дана величина набуває при $W=51 \%$.

Порівняння результатів чисельного моделювання процесів конвекційного сушіння зразка ККПМ 3 експериментальними результатами показало їх достатньо задовільне якісне узгодження. Водночас спостерігається певна розбіжність у кількісних показниках даних результатів. Отже, розглянута розрахункова модель може бути використана для наближеного визначення характеристик процесу сушіння столового буряка.

\section{Висновки}

Сформульовано фізичну модель тепломасопереносу в процесі конвекційного сушіння ККПМ. Проведено розрахункові та експериментальні дослідження 3 метою порівняння їх результатів. Порівняння результатів чисельного моделювання процесів конвекційного сушіння зразка ККПМ з експе-

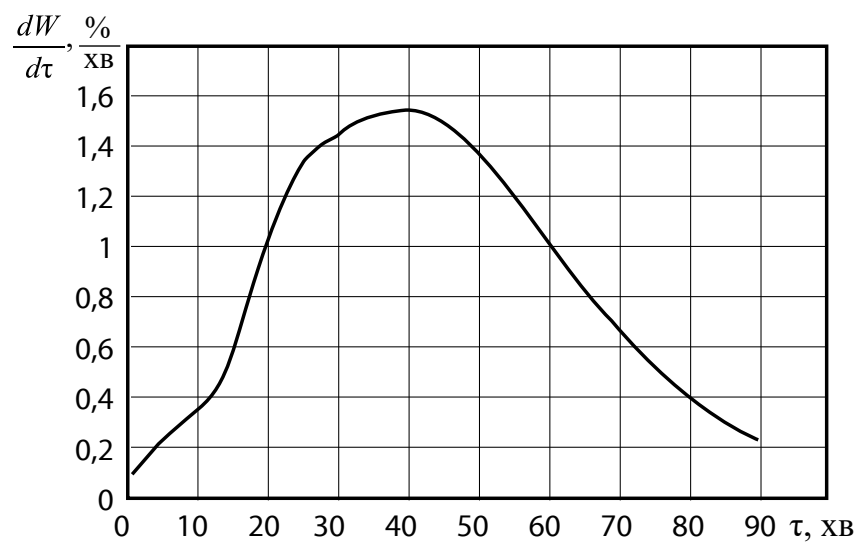

Рис. 9. Залежність від часу швидкості зміни відносної вологості зразка

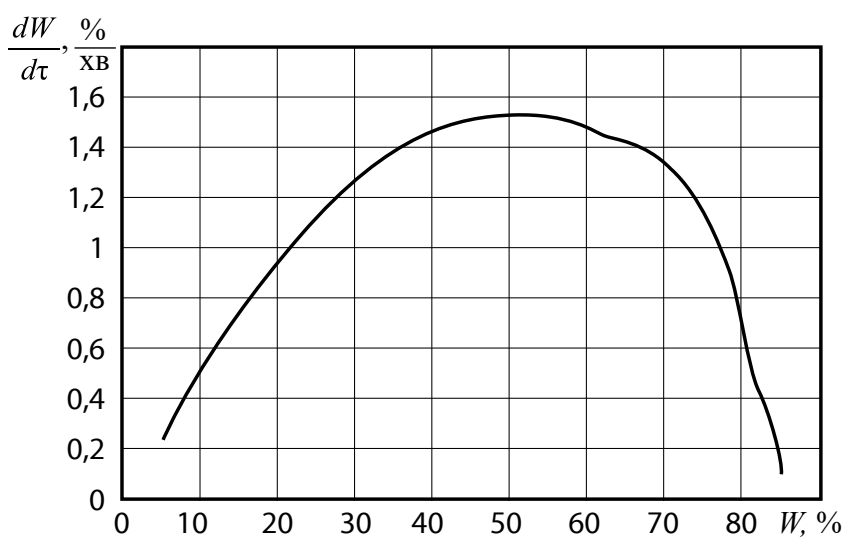

Рис. 10. Залежність швидкості зміни відносної вологості зразка від величини відносної вологості 
риментальними результатами показало їх достатньо задовільне якісне узгодження. Водночас спостерігається певна розбіжність у кількісних показниках даних результатів. Отже, розглянута розрахункова модель на основі запропонованої системи рівнянь може бути використана для наближеного визначення характеристик процесу сушіння ККПМ, зокрема часу, необхідного для висушування матеріалу.

Перспективи подальших досліджень. Моделювання тепломасообмінних процесів у колоїдних капілярно-пористих матеріалах сприяє вирішенню важливої науково-технічної проблеми, пов'язаної зі створенням програмно-технічних комплексів, автоматизованих систем наукових досліджень енергоощадних теплотехнологічних процесів сушіння матеріалів із забезпеченням необхідних показників якості [13]. Проаналізувавши літературні дані стосовно математичного моделювання колоїдних капілярно-пористих матеріалів встановлено, що даний напрям має обмежену кількість інформації і тому потребує поглибленого вивчення та $є$ актуальним напрямком досліджень.

\section{References}

1. Гайвась, Б. Математичне моделювання конвективного сушіння матеріалів 3 урахуванням механотермодифузійних процесів. Фізико-математичне моделювання та інформаційні технології. - 2010. Вип. 12. - С. 9 - 37.

2. Лыков, А.В. Теория сушки. - Москва: Энергия. 1968. - $372 \mathrm{c}$.

3. Рудобашта, С.П. Новые российские исследования в области сушки и термо-влажностных процессов. Современные энергосберегающие тепловые технологии (сушка и термовлажностная обработка материалов) СЭТТ-2008: труды III международной научно-практической конференции. - Москва. 2008. - T.1. - C. 4 - 15.

4. Сорокова, Н.M. Математичне моделювання ди- наміки тепломасопереносу в процесах сорбції і сушіння в апаратах періодичної і безперервної дії: дис. д - ра техн. наук: 05.14.06; 144 / Інститут технічної теплофізики НАН України. - Київ. - 2017. - 326 с.

5. Гайвась, Б.І. Математичне моделювання процесу сушіння пористих тіл з врахуванням кінетики фазових переходів та деформацій: автореф. дис. д-ра техн. наук: 01.0.02 / Національний університет «Львівська політехніка». - Львів. - 2012. - 40 с.

6. Борецька, I., Соколовський, Я. Математичне моделювання конвективного процесу сушіння деревини з урахуванням границь фазових переходів. Вісник Національного університету «Львівська політехніка». Серія: Комп'ютерні науки та інформаційні технології : збірник наукових праць. - 2015. - № 826. - С. 219 - 229.

7. Лькков, А.В. Теория тепломассопереноса / А.В. Лыков, Ю.В. Михайлов. - Москва: Госэнергоиздат. - 1963. - 462 с.

8. Dolinskiy, A.A., Dorfman, A.Sh., Davydenko, B. $V$. Conjugate heat and mass transfer in continuous processes of convective drying. Int. J. Heat Mass Transfer. - 1991. - V.34. - №11. - P. 2883 - 2889.

9. Михеев, М.А., Михеева, И.М. Основы теплопередачи. - Москва: Энергия. - 1977. - 320 с.

10. Гура, О.В. Дослідження кінетики сушіння пивної дробини в псевдозрідженому шарі. Вісник ЖДТУ. - 2014. - №3(70). - С. 103 - 108.

11. Калиткин, Н. Н. Численные методы. - Москва: Наука. - 1978. - 512c.

12. Гинзбург, А.С., Громов, М.А., Красовская, Г.И. Теплофизические характеристики пищевых продуктов: справочник. - Москва: Пищевая промышленность. $-1980 .-288$ с.

13. Соколовський, Я., Поберейко, Б. Моделювання взаємозв'язаних тепломасообмінних і деформаційно-релаксаційних процесів при сушінні гігроскопічних матеріалів. Вісник Національного університету «Львівська політехніка». - Львів. - 2007. - № 604. - С. 148 - 153. 